\title{
The Effect of Green Characteristics in Reducing the Inventory of Unsold Housing in New Residential Developments-A Case of Gyeonggi Province, in South Korea
}

\author{
Hayoung Yoo ${ }^{1,2}$ iD and Heeyeun Yoon $1,2,3, *$ \\ 1 Department of Landscape Architecture and Rural Systems Engineering, College of Agriculture and Life \\ Sciences, Seoul National University, 1 Gwanak-ro, Gwanak-gu, Seoul 08826, Korea; yoohy961129@snu.ac.kr \\ 2 Integrated Major in Smart City Global Convergence, Seoul National University, 1 Gwanak-ro, Gwanak-gu, \\ Seoul 08826, Korea \\ 3 Research Institute of Agriculture and Life Sciences, Seoul National University, 1 Gwanak-ro, Gwanak-gu, \\ Seoul 08826, Korea \\ * Correspondence: hyyoon@snu.ac.kr
}

Citation: Yoo, H.; Yoon, H. The Effect of Green Characteristics in Reducing the Inventory of Unsold Housing in New Residential Developments-A Case of Gyeonggi Province, in South Korea. Land 2021, 10, 377. https://doi.org/ 10.3390/land10040377

Academic Editor: Fabrizio Battisti

Received: 1 March 2021

Accepted: 30 March 2021

Published: 5 April 2021

Publisher's Note: MDPI stays neutral with regard to jurisdictional claims in published maps and institutional affiliations.

Copyright: (c) 2021 by the authors. Licensee MDPI, Basel, Switzerland. This article is an open access article distributed under the terms and conditions of the Creative Commons Attribution (CC BY) license (https:/ / creativecommons.org/licenses/by/ $4.0 /)$.
Abstract: This study analyzes the effect of green characteristics on sales of unsold housing stock, using a multilevel growth model, in Gyeonggi Province, South Korea from 2012 to 2018. The green characteristics we estimated are external factors such as the proximity to urban parks and mountain trails located outside the housing complex and internal factors such as whether the area of communal open space within the complex exceeds a certain percentage. The results suggest that potential homebuyers are interested in green space inside rather than outside a housing complex in a suburban setting. Housing complexes with large enough communal open spaces had a 0.094 higher unsold unit ratio than complexes with small communal open spaces, but the surplus decreased more rapidly; the ratio declines by 0.028 per time unit. On the other hand, the results show no statistically significant effects of the distance to external green areas. This might be due to that public urban parks might not be an attraction to residents when forests and/or agricultural fields are in close proximity. The findings of this research will be utilized by construction companies and public institutions holding unsold units in improving their sales performance, not only in South Korea but also in other Asian regions showing a similar housing development pattern.

Keywords: green characteristic; communal open spaces; housing market; unsold housing; suburban residential development; multilevel growth model

\section{Introduction}

Mismatch in the demand and supply of housing has been a worldwide concern. While many countries have suffered from the housing shortage, housing surplus also generates equally substantial problems. In cities of rapidly urbanizing countries, governments and private sectors have commonly implemented large-scale suburban residential development projects since the 1980s to resolve urban housing shortage and stabilize housing prices [1-3]. While such developments are still ongoing, a portion of the completed housing units have not been contracted for either before or during construction and remain unsold upon completion of the complex. The presence of unsold units creates a negative impression of the housing complex as a whole and further repels potential home-buyers [3-5]. This is likely to worsen the financial stability of the developers and negatively affect the local economy [6,7].

For example, between 1990 and 2000, the Beijing metropolitan government in China launched town development projects and doubled the existing housing stocks [8]. In Malaysia, under the Eighth Malaysian Housing plan, private contractors provided 303,000 housing units, $216.3 \%$ of the total targeted housings, to meet the basic housing needs of residents of large cities, including Kuala Lumpur and George Town, Penang [3,9]. In the case of Seoul, 
the capital of South Korea, large-scale suburban residential developments were begun in the 1980s to meet the soaring housing demand in the city [10]. In the first- and second-phase of so-called "new town" developments in the Seoul metropolitan area, housing was built to accommodate $5.8 \%$ (292,000 units) and $10.5 \%$ (665,800 units) of the population, respectively. Currently, the third-phase development is expected to provide 173,000 units, to bring the total constructed over the three phases to more than one million housing units [11,12].

A large portion of those developed housing units, however, have remained unsold. In Korea, about $25 \%$ of the pre-sale housing units in the metropolitan area are still unsold, while in China $20-30 \%$ are in that condition. Malaysia is in the same situation, in that $25.8 \%$ of the flats in newly developed towns were not taken $[3,4]$. The reasons for the unexpectedly low sales rate have been posited to include inconvenient locations, unattractive physical characteristics of the housing, and unfavorable financial arrangements in the transaction process. More importantly, however, public amenities that were not ready at the time the housing opened for occupancy, such as transport links and school systems, constitute the main factor that discouraged prospective home-buyers [2,13-15].

This means that improvement of the aforementioned conditions would spur the sales of the unsold housing stock. Improved accessibility of new road systems, the creation of recreational amenities, and/or the addition of educational institutions would raise the demand for those housing units [16,17]. Shorter commutes are an important merit, hence the creation of new jobs by the relocation of industrial or office complexes to the vicinity would exert similar effects $[18,19]$. In addition, economic and institutional support for consumers of housing, such as reducing the real estate acquisition tax and relaxing the loan-to-value ratio (LTV), also appeared to be important factors [14,20].

In densely developed urban residential settings, it is reported that green amenities such as parks and open spaces play an important role in creating a pleasant living environment [21-23]. Those preferences have been incorporated into urban housing prices [24-26]. People living in densely developed cities place greater value on natural greenery, perhaps due to the shortage of such recreational resources $[27,28]$. It was also found that people prefer semi-public or private green spaces within housing complexes [29-31].

Although mounting numbers of studies have investigated the preferences of the green amenities reflected in the housing values in urban settings, equivalent studies on unsold housing units in suburban residential developments are limited [13]. While buyers of that particular type of housing are known to consider mainly the proximity to cities, transportation, and job locations when deciding where to live [32,33], their preference of green amenities has not been the subject of the analysis. Though anecdotal evidence suggests that green amenities are attractions for them as well [22,25], the actual contribution of such amenities to reducing unsold suburban housing stock has not yet been studied.

Against that backdrop, this study empirically investigates the effectiveness of green amenities in inducing the sale of unsold housing stock in the suburban residential development projects in Gyeonggi Province, South Korea. The site deserves attention, since over the last three decades, from 1990 to 2019, the Seoul metropolitan area has suffered from unprecedented surpluses of housing. Our study period is from 2012 to 2018, and we use a multilevel growth model to reveal the effect of green amenities on changes in unsold housing inventory over the multiyear selling period.

The structure of this study is as follows. First, we briefly review the history and the current status of unsold housing stock within the study site, as well as previous studies on the reduction of unsold housing units. Then we describe the analytical design, including the data and statistical modeling. After presenting the results, we conclude with a discussion of the implications of our findings and future research directions.

\section{Background and Literature Review}

\subsection{Unsold Housing in Gyeonggi Province, South Korea}

Beginning in the 1960s, South Korea began to undergo rapid economic growth, accompanied by industrialization and urbanization. Housing demand in cities has escalated, 
and so have housing prices [14]. In order to stabilize housing prices, the government has continuously implemented plans to expand the housing supply. Some of these resulted in oversupply; the most prominent example is the "Two Million Housing Unit Construction Plan" of the late 1980s. Following several unsuccessful large-scale housing developments and the national economic downturn during the last 30 years, a large number of housing units remained unsold [13]. For example, shortly after the domestic and global financial crises in 1997 and 2008, more than 120,000 and 160,000 unsold housing units accumulated in the nationwide housing market. With the government measures to address the issue-such as exemption from transfer tax and reduction of registration tax [6] - the quantity of unsold housing units has been fluctuating [34]. As of 2018, the number of unsold housing units in the Seoul metropolitan area was about 8700 . Figure 1 depicts the level of unsold housing stock over the past 30 years.

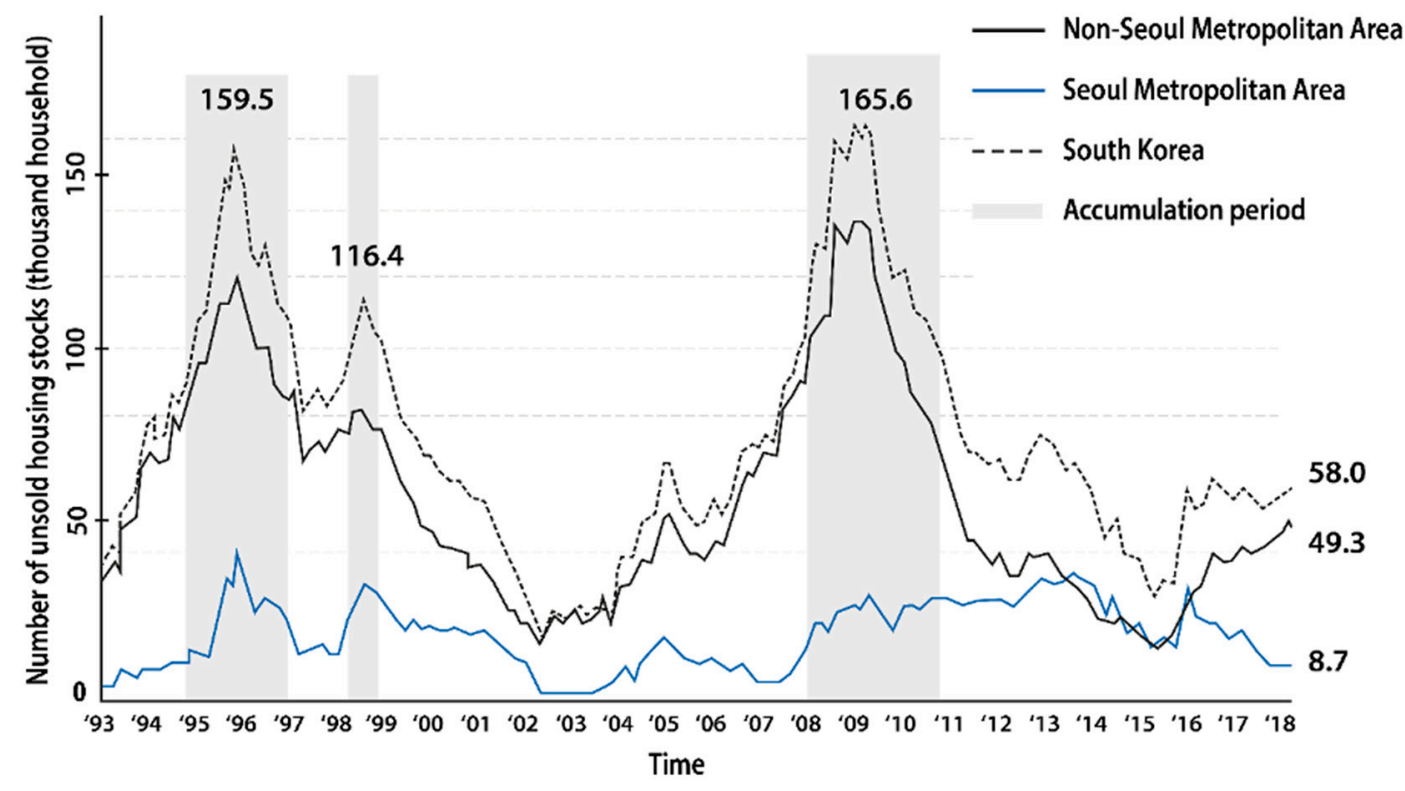

Figure 1. Unsold housing stock in South Korea (1993-2018).

Unsold housing inventories cause problems not only to contractors and developers but also to the local real estate markets. A higher proportion of vacant units may cause safety problems, unsettling the residents of the subject housing complex $[3,35]$. Residents also have to assume the increased administrative costs for maintaining the unsold units. In addition, the developers often lower the housing price to increase the sales volume, generating opposition from the residents who bought the equivalent units at higher prices earlier [36]. This situation has a negative impact on the nearby housing markets, which puts a heavy burden on the local economy [7].

In South Korea, most of the large-scale housing developments adopt the pre-construction sales system, the so-called "lotting-out" or "pre-sale" system, in which home-buyers apply for a housing unit in a draw and deposit money to be used for the construction. If money is undersupplied due to the low rate of pre-sales, construction companies are forced to stop the process, change the design, or use low-quality materials to reduce the construction cost $[37,38]$.

\subsection{Factors Affecting the Sales of Newly Developed Housing Units in the Suburbs}

First of all, improved accessibility to important destinations raises the demand for the subject housing units. Liu et al. [39], in their study in Hangzhou, China, suggest that travel time to the central business district, distance to urban arteries, distance to schools and colleges, and distance to the Qiantang River are the main significant variables that positively encourage migration to suburban residential developments. Shen and Wu [40] 
also measured the demand-side driving forces of suburban growth in China, with a random survey in Songjiang, Shanghai. A good living environment, employment opportunities, cheap housing price, rapid access to central districts, and high-quality estates were five factors that made suburban development feasible. In addition, Ko et al. [32] suggest that traffic accessibility (as represented by the number of adjoining roadways), good schools, and a natural and green environment can affect the pre-sale performance of housing units in suburbs in South Korea.

Second, the structural characteristics of housing complexes affect the housing demand, so developers offer diversified combinations of unit types and sizes to cater to consumers' needs and tastes. Kim and Lee [41] revealed that the total height of the building, the proportion of the unit below $85 \mathrm{~m}^{2}$ - which is a common size of a housing unit in Korea-has positive effects on the rate of real transactions. They also suggested that larger apartment complexes were preferred, resulting in higher initial pre-sale rates for complexes with greater numbers of units.

Finally, certain macroeconomic indices and/or real estate policies affect housing demand. Hur and Son [42] investigated the effectiveness of policies related to unsold housing. The relaxation of financial regulations-debt-to-income (DTI) ratio and loanto-value (LTV) ratio-has a larger effect on the reduction of the unsold housing stock (coeff. $=-0.273, p<0.01$ ). Kwon and Bang [43] found that an increase of the LTV ratio (coeff. $=-1.625, p<0.01$ ), allowing resale of pre-sale housing, and real estate sales tax remission each had a statistically significant effect on the aforementioned condition.

The quality of living environments also matters. According to a survey conducted by Kim [44], 27.4\% of those who moved to suburban housing in South Korea sought a pleasant natural environment. In addition, Lee and Lee [45] suggested that applicants for pre-sale housing units preferred to have communal areas for social interactions within the housing complexes (path coefficient $=0.204, t-v a l u e=1.783$ ). Tak and Rho [46] produced the suggestion that landscaped areas in the complex had a significant effect on tenants' decisions to purchase unsold apartments (VIP-Variable Importance in the Projection $=1.107$ ).

Our study here aligns with the last two studies in terms of the research question, but it differs in more advanced ways. First, those studies, based on surveys, examined the stated preferences of the residents. Our current study, on the other hand, examines the revealed preferences of the residents by estimating the reduction of unsold unit ratio as a dependent variable and thus is free from all kinds of response bias. Second, the previous studies took only a few sites as the subject of investigation. In that setting, the comparison of a wide range of locational attractions with green amenities would not be possible in assessing the preference, because the site contexts vary substantially from case to case. Our current study takes all of the housing complexes in a province as the subject, hence higher generalizability is warranted. Third, we use a growth model to assess the changes in the unsold housing inventory over time. This technique allows for more detailed insights than does the cross-sectional approach.

\subsection{Green Factors Affecting the Price of Housing Units in Urban Settings}

Research using hedonic modeling revealed that proximity to public green spaces adds extra value to residential units in urbanized areas. Czembrowsi and Kronenberg [47] suggested that the percentage of green space in a $500 \mathrm{~m}$ radius positively influenced the housing prices. Eom et al. [48] investigated that residents in Seoul, South Korea, preferred rivers and urban parks within a 10-min distance of their housing complexes. Among those, the value added by urban parks (coefficient $=0.023, p<0.01$ ) is estimated as two to three times higher than that of the river (coefficient $=0.039$, respectively). Trojanek et al. [49], in their study in Warsaw, the capital city of Poland, found that proximity to urban parks within $100 \mathrm{~m}$ from the housing complex increased the housing price by $2.8 \%$ to $3.1 \%$.

The residents also prefer the proximity to natural landscapes such as forests and mountains. Czembrowski and Kronenberg [47] revealed that a one percent increase in the distance to the Lagiewniki forest (over 13,000,000 $\mathrm{m}^{2}$ ) in Lodz, a city in Poland, decreased 
the housing price by $3 \%$ on average. In a study in Seoul, South Korea, Choi and Eom [50] found that housings within a 10-min distance to a forest earned an average value premium of $17 \%$. In addition, housings with mountain/forest views had a price premium of $33 \%$ compared to those without a view.

The presence of semi-public green spaces within housing complexes also positively influences the price of housing units. Hong [29] mentioned that communal open spaces per household were the main significant variables increasing housing value (coefficient $=13.222$, $p<0.01$ ). Park et al. [30], in their study in Jeonju, South Korea, revealed the five main green components within housing complexes that potential and current residents preferred: trees, streams, trails, flowerbeds, and fountains. Xiao et al. [31], in their study in Shanghai, China, found that internal green spaces of housing complex substitute for publicly supplied green spaces, accounting for an 8.7\% increase in housing prices. Chen and Jim [51], in their study in Shenzhen in China, showed the visibility of greenery in communal gardens was associated with a $17.2 \%$ increase in housing prices.

Table 1 is added to categorize various aforementioned refereneces into three main themes according to the subtitles in our literature review.

Table 1. Studies included in the literature review.

\begin{tabular}{|c|c|c|}
\hline Theme & Findings & Source \\
\hline \multirow{4}{*}{$\begin{array}{l}\text { Unsold housing in Gyeonggi } \\
\text { Province, South Korea }\end{array}$} & $\begin{array}{c}\text { Housing demand and housing prices in cities } \\
\text { have escalated. }\end{array}$ & Jo and Kim, 2010 [14] \\
\hline & $\begin{array}{l}\text { Following unsuccessful large-scale housing } \\
\text { developments in the period of economic downturn, a } \\
\text { large number of housing units remained unsold. }\end{array}$ & Jang and Lee, 2010 [13] \\
\hline & $\begin{array}{l}\text { With the government measures, the quantity of unsold } \\
\text { housing units has been fluctuating. }\end{array}$ & $\begin{array}{c}\text { Kim, } 2007 \text { [6] } \\
\text { Kang, } 2018 \text { [34] }\end{array}$ \\
\hline & $\begin{array}{l}\text { The high proportion of vacant units causes safety } \\
\text { problems for the residents, has a negative impact on } \\
\text { the nearby housing market, and forces the } \\
\text { construction companies. }\end{array}$ & $\begin{array}{c}\text { Tan, } 2011 \text { [3] } \\
\text { Shin, } 2012 \text { [35] } \\
\text { Poovenraj, } 2020 \text { [36] } \\
\text { Choi et al., } 2013 \text { [37] } \\
\text { Song, 2017 [38] }\end{array}$ \\
\hline \multirow{4}{*}{$\begin{array}{l}\text { Factors affecting the sales of } \\
\text { newly developed housing } \\
\text { units in the suburbs }\end{array}$} & $\begin{array}{l}\text { Improved accessibility to important destinations raises } \\
\text { the demand for the subject housing units. }\end{array}$ & $\begin{array}{l}\text { Liu et al., } 2015 \text { [39] } \\
\text { Shen and } \mathrm{Wu}, 2013 \text { [40] }\end{array}$ \\
\hline & $\begin{array}{l}\text { The structural characteristics of housing complexes } \\
\text { affect the housing demand. }\end{array}$ & Kim and Lee, 2018 [41] \\
\hline & $\begin{array}{l}\text { Certain macroeconomic indices and/or real estate } \\
\text { policies affect housing demand. }\end{array}$ & $\begin{array}{l}\text { Hur and Son, } 2013 \text { [42] } \\
\text { Kwon and Bang, } 2016 \text { [43] }\end{array}$ \\
\hline & $\begin{array}{l}\text { The quality of living environment affects } \\
\text { housing demand. }\end{array}$ & $\begin{array}{c}\text { Kim, } 2014[44] \\
\text { Lee and Lee, } 2014[45] \\
\text { Tak and Rho, } 2017[46]\end{array}$ \\
\hline \multirow{3}{*}{$\begin{array}{l}\text { Green factors affecting the } \\
\text { price of housing units in } \\
\text { urban settings }\end{array}$} & $\begin{array}{l}\text { Proximity to public green spaces adds extra value to } \\
\text { residential units. }\end{array}$ & $\begin{array}{c}\text { Czembrowski and Kronenberg, } 2016 \text { [47] } \\
\text { Eom et al., 2019 [48] } \\
\text { Trojanek et al., } 2018 \text { [49] }\end{array}$ \\
\hline & $\begin{array}{l}\text { Proximity to natural landscapes such as forests and } \\
\text { mountains is preferred by residents. }\end{array}$ & $\begin{array}{l}\text { Czembrowski and Kronenberg, } 2016 \text { [47] } \\
\text { Choi and Eom, } 2017 \text { [50] }\end{array}$ \\
\hline & $\begin{array}{l}\text { The presence of semi-public green spaces within } \\
\text { housing complexes positively influences. The price of } \\
\text { housing units. }\end{array}$ & $\begin{array}{c}\text { Hong, 2014 [29] } \\
\text { Park et al., 2016 [30] } \\
\text { Xiao et al., 2016 [31] } \\
\text { Chen and Jim, 2010 [51] }\end{array}$ \\
\hline
\end{tabular}




\section{Analytical Design}

\subsection{Research Question}

This study analyzes the effect of green amenities on the reduction of unsold housing stock in new residential development projects in Gyeonggi Province, South Korea, from November 2012 to December 2018. We hypothesize that the effect of green amenities increases the housing demand and consequently has helped to reduce the unsold housing stock.

\subsection{Study Site and Period}

The study site is Gyeonggi Province, the largest region in the Seoul metropolitan area. The province has had a large number of unsold housing units since the end of 2007 [34]. Figure 2 depicts the location of the housing complexes in the sample and the green amenities within the study site. Figure 3 provides examples of housing complexes under investigation, including valued/not-valued green amenities by the potential home buyers within or in the vicinity of the complex.

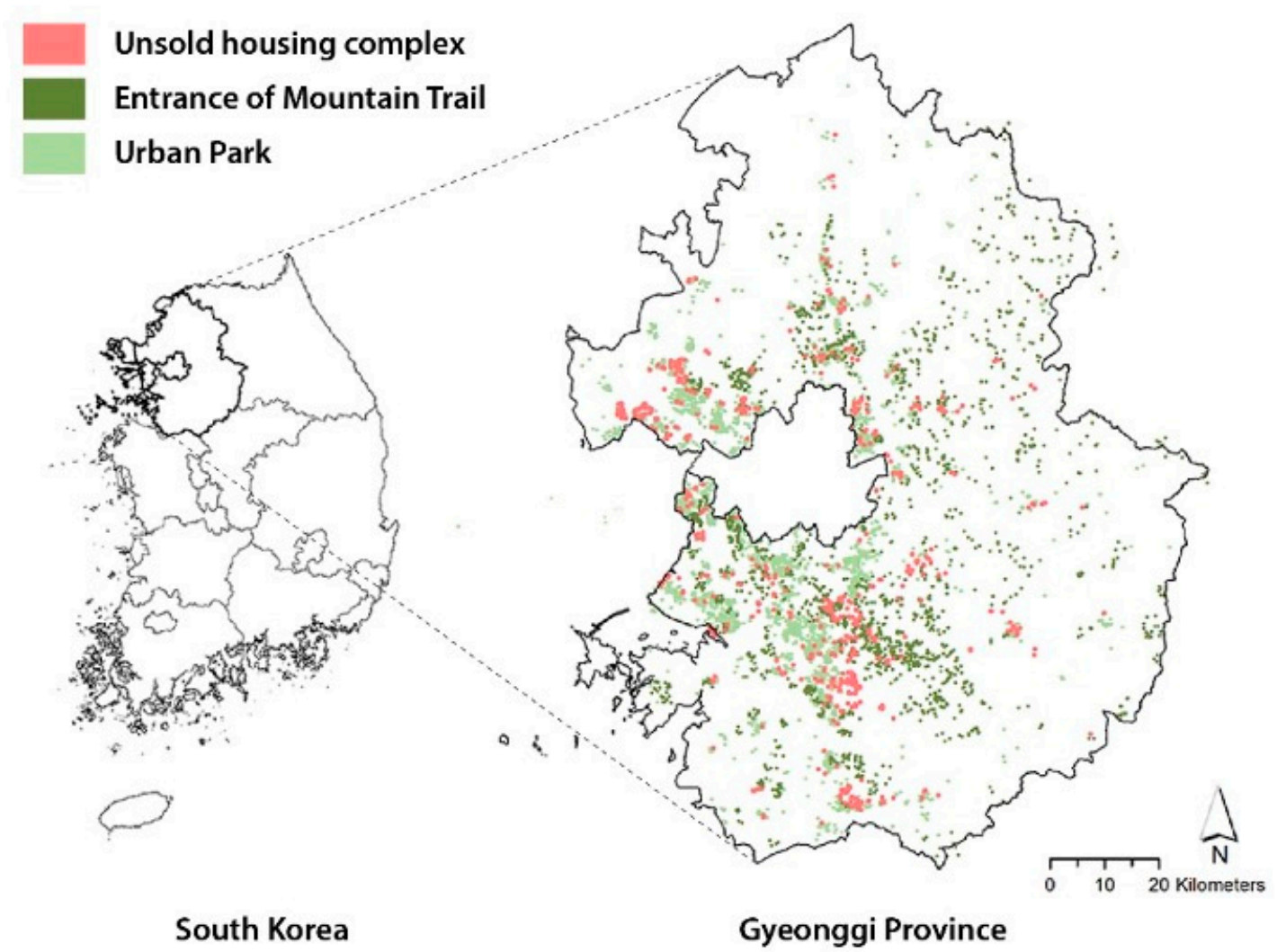

Figure 2. The locations of urban parks and entrances of mountain trails surrounding unsold housing complexes in Gyeonggi Province, South Korea, from 2012 to 2018.

The study period is from November 2012 to December 2018, determined by the data availability. In Korea, in the case of large-scale residential developments and under the presale or lotting-out system, sales normally begin two or three years before the completion of construction [52]. 
(a) Large-scale housing complex

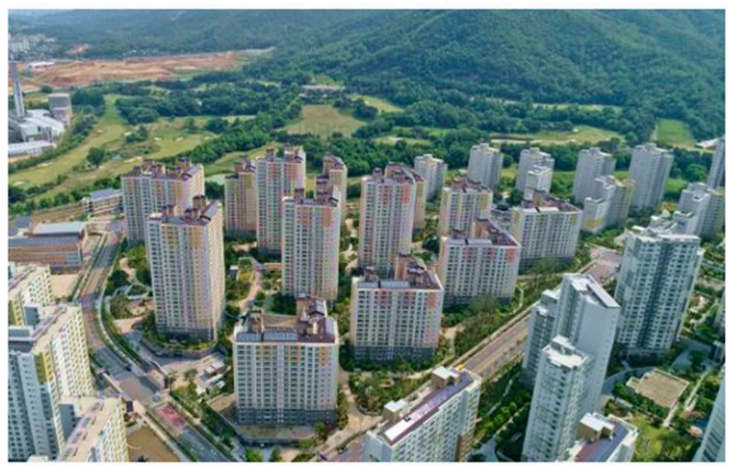

\section{(c) Urban park}

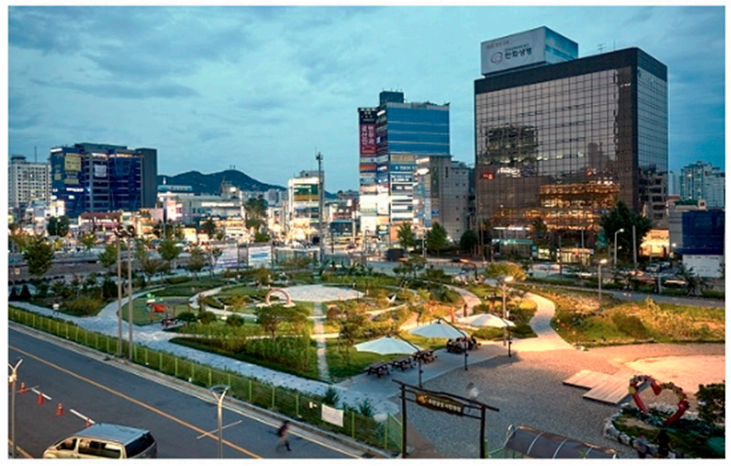

(b) Communal open spaces (semi-public garden)

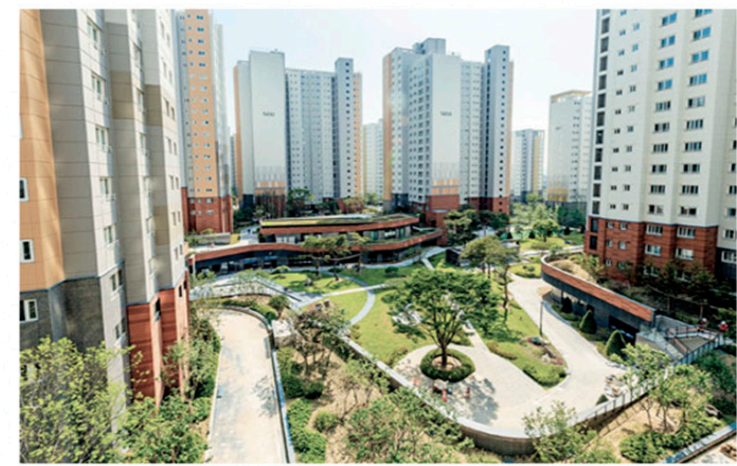

(d) Mountain trail entrance

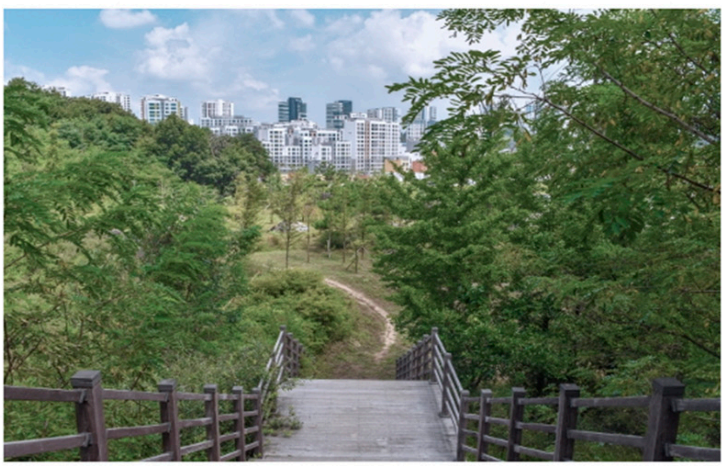

Figure 3. Aerial views of housing complexes and internal/external green amenities in Gyeonggi Province-Large-scale housing complexes, semi-public garden of communal open spaces, urban parks and mountain trail entrance, in order (Source: [53-56]).

\subsection{Data}

The primary dataset is the inventory of unsold housing in Gyeonggi Province collected by the local government of the province from 2012 to 2018. The data include information on 3740 housing complexes: monthly inventories of unsold housing units, contractor, developer, and floor area of each unit. The locations of green amenities were acquired from multiple sources. The locations of the urban parks were collected from the Gyeonggi Data Source. The locations of the trail entrances were collected from the Korea Forest Service. For other types of housing complex characteristics, such as communal open spaces ratio, floor area of housing unit, brand, and the number of households in each housing complex, we used the site Real Estate 114, a private real estate portal site. The locations of various amenities such as traffic facilities, business districts, and convenient facilities were sourced from the Public Data Portal site. The macroeconomic indices were collected from the Real Estate Statistics Information System, and the information on policy related to real estate was provided by the Ministry of Land, Infrastructure and Transport (MOLIT).

\subsection{Measures}

Our dependent variable is the ratio of unsold housing units to the total housing units for sale in each housing complex (Unsold_Unit_Ratio). It is recorded for the first time when the first sales application window is closed, and recording is repeated every month. Our question variable is green amenities. We considered the distance to the nearest urban park, including waterfront parks, neighborhood parks, urban agriculture parks, cemeteries, cultural parks, etc. (Dist_Urban_park), and the log of the nearest entrance to a trail in a natural park (In (Dist_Mountain_trail)). To express the context of proximity, the distance was measured from the centroid of a housing complex to that of the nearest urban park or to the entrance point of the nearest mountain trail in a lineal from on a map. For the 
communal open space within a housing complex — semi-public recreational facilities such as gardens and plazas-we used the non-building-to-land ratio of the complex as a proxy variable. In general, a $20 \%$ building coverage is considered favorable in large-scale housing complexes [57-59]. Applying the criterion, we specified a dummy variable indicating whether the ratio of the communal open space exceeded $80 \%$ or not (Communal_OpenSpace).

Three groups of control variables were considered: locational factors, structural characteristics of the housing complex, and economic factors. Locational factors indicate the distance to the nearest amenities of various types. In Korea, location is one of the most critical factors in choosing where to live, because people value accessibility to the places where social and economic activities take place [60]. Log transformation was used to manage the skewed locational data; examples are the distance to the nearest transportation facilities (arterial roads, $\ln$ (Dist_Arterial_road); subway station, ln (Dist_Subway_station)), business districts (industrial complexes, In (Dist_Industrial_complex)), central business districts and the center of Seoul (ln (Dist_CBD_Seoul), ln (Dist_Seoul)), river (ln (Dist_River)), and other convenient facilities (hospital, ln (Dist_Hospital); government office, ln (Dist_Government_office); shopping mall, ln (Dist_Shoppint_mall)). The linear distances were measured from the point and/or line of each amenity to the centroid point of the housing complex. For structural characteristics of the housing complexes, we included the floor area of each housing unit as a dummy variable by classifying apartments based on floor area of 60 , 85,102 , and $135 \mathrm{~m}^{2}$ (respectively, Area_floor_60 $\mathrm{m}^{2} \_$to_85 $\mathrm{m}^{2}$, Area_floor_85 $\mathrm{m}^{2} \_$to_102 $\mathrm{m}^{2}$, Area_floor_102 $\mathrm{m}^{2}$ _to_135 $\mathrm{m}^{2}$, Area_floor_larger_than_135 $\mathrm{m}^{2}$ ), the brand of the developer (whether the housing units are built by one of the major construction companies, brand), and $\log$ of the number of household units in each complex (ln (Number_Household)). More detailed structural features, such as individual heating systems, underground parking lot, and additional facilities inside the housing complex, are not included in the model, due to the unavailability of data. Economic factors include the macroeconomic conditions: economy growth rate (Economy_growth_rate), mortgage rate (Mortgage_rate), and housing policies implemented during the study period (Financial_Policy). Detailed descriptions of the variables are presented in Appendix A.

\subsection{Analytical Plan}

We adopted multilevel growth modeling to assess how the number of unsold units in the housing complexes changed over time under the influences of the various factors $[61,62]$. Multilevel growth models are a special case of random coefficient models, which focus on time coefficients that vary randomly between the analytical units [61,62]. The model was constructed as two-level, allowing for the exploration of both intra-individual change and individual differences in the nature of that change [63]. The individual in this study is each housing complex. We first conducted two forms of unconditional modeling: (1) unconditional means modeling, also referred to as an intercept-only model or a null model [64], to check the proportion of the outcome variance explained by the within and between housing complexes, and, (2) unconditional growth modeling to see whether longitudinal variability presents [65-67].

The unconditional means model is expressed for the $i$ th housing complex and $t$ th period by Function (1):

$$
\begin{array}{cc}
\text { Level }-1: & \text { UnsoldUnitRatio } \\
\text { Level }-2: & \pi_{0 i}=\beta_{0}+r_{0 i}
\end{array}
$$

where, $\varepsilon_{i t} \sim \mathrm{N}\left(0, \sigma_{\varepsilon}^{2}\right)$ and $r_{0 i} \sim \mathrm{N}\left(0, \sigma_{0}^{2}\right)$.

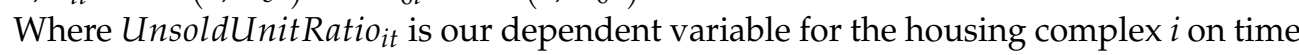
period $t, \pi_{0 i}$ is the mean of the unsold housing ratio for housing complex $i, \beta_{0}$ is the grand mean of the unsold housing ratio for all housing complexes. $\varepsilon_{i t}$ is the deviation from the mean $\left(\pi_{0 i}\right)$ for complex $i$ on time period $t$, and $r_{0 i}$ is the deviation from the grand mean $\left(\beta_{0}\right)$ for the individual mean $\pi_{0 i}[63,68]$. 
The unconditional growth model incorporates time variable Time $i t$ into the unconditional means model [64]. The regression coefficient of Time, $\pi_{1 i}$ is included for housing complex $i$ to represent the growth rate unique to each housing complex, random effects $r_{1 i}$ is included; in other words, the random effects or the variance components imply the variability of the outcome [69]. The model is presented below as Function (2):

$$
\begin{array}{cc}
\text { Level }-1: & \text { UnsoldUnitRatio } \\
\text { Level }-2: & =\pi_{0 i}+\pi_{1 i} \text { Time }_{i t}+\varepsilon_{i t} \\
\pi_{0 i}=\beta_{0}+r_{0 i} \\
\pi_{1 i}=\beta_{1}+r_{1 i}
\end{array}
$$

where, $\varepsilon_{i t} \sim \mathrm{N}\left(0, \sigma_{\varepsilon}^{2}\right)$ and $\left[\begin{array}{l}r_{0 i} \\ r_{1 i}\end{array}\right] \sim \mathrm{N}\left(\left[\begin{array}{l}0 \\ 0\end{array}\right],\left[\begin{array}{cc}\sigma_{0}^{2} & \sigma_{01} \\ \sigma_{01} & \sigma_{1}^{2}\end{array}\right]\right)$.

In the main model, Level-1 includes time-varying variables, and Level-2 includes time-invariant variables. Consequently, the time variable and the distance to the amenities and economic indices become a component of the Level-1 model. Structural characteristics of housing complexes, including communal open spaces, are time-invariant variables, and they are included in the Level-2 model.

The transactions were recorded for each complex repeatedly at multiple time points. The sales period differs by housing complex, hence the unbalanced panel data: 60,593 unsold units in 3740 housing complexes. We plotted the mean of observed unsold unit ratio during the study period to examine the growth pattern (Figure 4). The ratio of unsold housing units showed a trend of declining non-linearly, as many other growth processes have revealed [63].

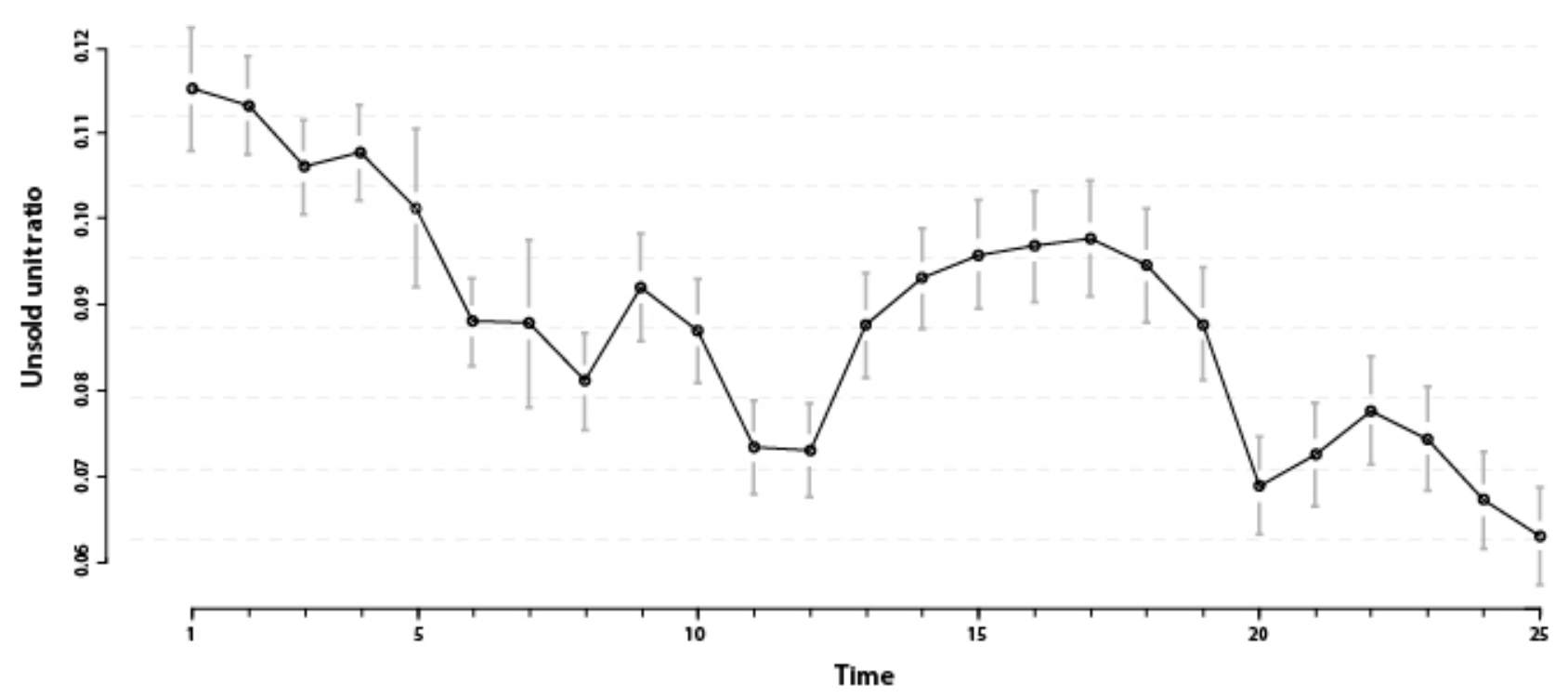

Figure 4. Observed growth in the mean ratio of total unsold units by time.

To allow varying trajectories by the effect of the communal open space, we added the interaction term with the time variable in the model. We initially compared the models with the main and interaction effects of all three of the green amenity variables, and we found that the one with the communal open space variable fit the data the best $[63,64]$. 
The final model was specified as below: for the $i$ th housing complex and $t$ th period.

Level -1 :

Level -2 :

$$
\text { UnsoldUnitRatio }_{i t}=\pi_{0 i}+\pi_{1 i} \text { Time }_{i t}+\beta_{3} U P_{i t}+\beta_{4} T R_{i t}+\beta_{5} L_{i t}+\beta_{6} E_{i t}+\varepsilon_{i t}
$$

$$
\begin{gathered}
\pi_{0 i}=\beta_{0}+\beta_{01} C O_{i}+\beta_{02} S_{i}+r_{0 i} \\
\pi_{1 i}=\beta_{1}+\beta_{11} C O_{i}+r_{1 i}
\end{gathered}
$$

where, $\varepsilon_{i t} \sim \mathrm{N}\left(0, \sigma_{\varepsilon}^{2}\right)$ and $\left[\begin{array}{l}r_{0 i} \\ r_{1 i}\end{array}\right] \sim \mathrm{N}\left(\left[\begin{array}{l}0 \\ 0\end{array}\right],\left[\begin{array}{ll}\sigma_{0}^{2} & \sigma_{01} \\ \sigma_{01} & \sigma_{1}^{2}\end{array}\right]\right)$.

Composite model :

UnsoldUnitRatio ${ }_{\text {it }}$

$$
\begin{aligned}
& =\beta_{0}+\beta_{1} \text { Time }_{i t}+\beta_{11} C O_{i} * \text { Time }_{i t}+\beta_{01} C O_{i}+\beta_{3} U P_{i t}+\beta_{4} T R_{i t} \\
& +\beta_{5} L_{i t}+\beta_{02} S_{i}+\beta_{6} E_{i t}+\left(\varepsilon_{i t}+r_{0 i}+r_{1 i} \text { Time }_{i t}\right)
\end{aligned}
$$

Time $_{i t}$ : the vector of time measurement.

$U P_{i t}$ : distance to the nearest urban park from housing complex $i$ in time period $t$.

$T R_{i t}$ : distance to the nearest entrance of mountain trail from housing complex $i$ in time period $t$.

$\mathrm{CO}_{i}$ : dummy variable for whether the communal open spaces in housing complex $i$ exceeded $80 \%$ or not.

$L_{i t}$ : a vector of location factors for housing complex $i$ in time period $t$.

$S_{i}$ : a vector of structural characteristics of the housing complex.

$E_{i t}$ : a vector of economic factors for housing complex $i$ in time period $t$.

$\varepsilon_{i t}$ : Level-1 residual. $r_{0 i}, r_{1 i}$ : Level-2 residual.

\begin{tabular}{|c|c|c|c|}
\hline Variable & $\begin{array}{l}\text { Unconditional } \\
\text { Means Model }\end{array}$ & $\begin{array}{l}\text { Unconditional } \\
\text { Growth Model }\end{array}$ & Final Model \\
\hline \multicolumn{4}{|c|}{ Question variables } \\
\hline Time & & $\begin{array}{c}-0.026^{* * *} \\
(0.001)\end{array}$ & $\begin{array}{c}-0.019 \text { *** } \\
(0.001)\end{array}$ \\
\hline UP (Dist_Urban_park) & & & $\begin{array}{l}-0.0003 \\
(0.0003)\end{array}$ \\
\hline TR (ln (Dist_Mountain_trail)) & & & $\begin{array}{l}-0.005 \\
(0.004)\end{array}$ \\
\hline CO (Communal_OpenSpace) & & & $\begin{array}{c}0.094^{* * *} \\
(0.026)\end{array}$ \\
\hline Time *CO (Communal_OpenSpace) & & & $\begin{array}{c}-0.009^{* * *} \\
(0.002)\end{array}$ \\
\hline \multicolumn{4}{|c|}{ Location variables } \\
\hline $\ln$ (Dist_Arterial_road) & & & $\begin{array}{c}-0.008^{* *} \\
(0.004)\end{array}$ \\
\hline ln (Dist_Subway_station) & & & $\begin{array}{l}-0.002 \\
(0.002)\end{array}$ \\
\hline ln (Dist_Industrial_complex) & & & $\begin{array}{c}0.031^{* * *} \\
(0.004)\end{array}$ \\
\hline $\ln$ (Dist_Hospital) & & & $\begin{array}{c}0.001 \\
(0.001)\end{array}$ \\
\hline ln (Dist_Government_office) & & & $\begin{array}{c}0.007 \\
(0.007)\end{array}$ \\
\hline
\end{tabular}

\section{Results}

Table 2 presents the results of the three models evaluated here: the unconditional means model, the unconditional growth model, and the multilevel growth model.

Table 2. Results of multilevel growth model including other factors. 
Table 2. Results of multilevel growth model including other factors.

\begin{tabular}{|c|c|c|c|}
\hline Variable & $\begin{array}{l}\text { Unconditional } \\
\text { Means Model }\end{array}$ & $\begin{array}{l}\text { Unconditional } \\
\text { Growth Model }\end{array}$ & Final Model \\
\hline \multicolumn{4}{|c|}{ Location variables } \\
\hline ln (Dist_Shopping_mall) & & & $\begin{array}{l}0.003^{* * *} \\
(0.001)\end{array}$ \\
\hline $\ln ($ Dist_CBD_Seoul) & & & $\begin{array}{l}0.034 \\
(0.03)\end{array}$ \\
\hline $\ln ($ Dist_Seoul) & & & $\begin{array}{l}0.033^{* *} \\
(0.014)\end{array}$ \\
\hline $\ln ($ Dist_River) & & & $\begin{array}{l}-0.024^{* * *} \\
(0.004)\end{array}$ \\
\hline \multicolumn{4}{|c|}{ Structural characteristics of housing complexes variables } \\
\hline Area_floor_60 $\mathrm{m}^{2} \_$to_85 $\mathrm{m}^{2}$ & & & $\begin{array}{l}-0.026^{* *} \\
(0.011)\end{array}$ \\
\hline Area_floor_85 $\mathrm{m}^{2} \_t o \_102 \mathrm{~m}^{2}$ & & & $\begin{array}{l}-0.076^{* * *} \\
(0.027)\end{array}$ \\
\hline Area_floor_102 $\mathrm{m}^{2} \_$to_135 $\mathrm{m}^{2}$ & & & $\begin{array}{l}-0.094^{* * *} \\
(0.023)\end{array}$ \\
\hline Area_floor_larger_than_135 m² & & & $\begin{array}{l}-0.077^{* * *} \\
-0.028\end{array}$ \\
\hline Brand & & & $\begin{array}{c}0.002 \\
(0.003)\end{array}$ \\
\hline ln (Number_Households) & & & $\begin{array}{l}-0.022 * * * \\
(0.005)\end{array}$ \\
\hline \multicolumn{4}{|c|}{ Economic variables } \\
\hline Financial_Policy_01/04/2013 & & & $\begin{array}{l}0.004^{* * *} \\
(0.001)\end{array}$ \\
\hline Financial_Policy_01/09/2014 & & & $\begin{array}{l}0.0002 \\
(0.001)\end{array}$ \\
\hline Financial_Policy_28/04/2016 & & & $\begin{array}{l}0.005^{* * *} \\
(0.001)\end{array}$ \\
\hline Financial_Policy_02/08/2017 & & & $\begin{aligned}-0.017^{* * *} \\
(0.001)\end{aligned}$ \\
\hline Economy_growth_rate & & & $\begin{array}{l}-0.003^{* * *} \\
(0.001)\end{array}$ \\
\hline Mortgage_rate & & & $\begin{array}{l}0.017^{* * *} \\
(0.002)\end{array}$ \\
\hline \multicolumn{4}{|c|}{ Fixed Effects } \\
\hline Constant & $\begin{array}{l}0.094^{* * *} \\
(0.002)\end{array}$ & $\begin{array}{l}0.436 * * * \\
(0.011)\end{array}$ & $\begin{array}{l}0.208 * * \\
(0.081)\end{array}$ \\
\hline \multicolumn{4}{|c|}{ Random Effects } \\
\hline \multicolumn{4}{|c|}{ Level 1 (within housing complex) } \\
\hline Residual $\left(\sigma_{\varepsilon}^{2}\right)$ & 0.0097 & 0.004 & 0.0039 \\
\hline \multicolumn{4}{|c|}{ Level 2 (between housing complex) } \\
\hline Mean Initial Status $\left(\sigma_{0}^{2}\right)$ & 0.0149 & 0.3789 & 0.4213 \\
\hline Mean Rate of Change $\left(\sigma_{1}^{2}\right)$ & & 0.0014 & 0.0014 \\
\hline Rate of Change Covariance $\left(\sigma_{01}\right)$ & & -0.89 & -0.91 \\
\hline $\begin{array}{l}\text { Intraclass Correlation Coefficient } \\
\text { (ICC) }\end{array}$ & $60.50 \%$ & $80.20 \%$ & $80.80 \%$ \\
\hline Observations & 60,593 & 60,593 & 60,593 \\
\hline Log Likelihood & $49,001.20$ & $66,510.51$ & $66,810.23$ \\
\hline Akaike Inf. Crit. & $-97,996.400$ & $-133,009.000$ & $-133,552.500$ \\
\hline Bayesian Inf. Crit. & $-97,969.360$ & $-132,954.900$ & $-133,246.100$ \\
\hline
\end{tabular}




\subsection{Unconditional Means Model}

The analytical result of the unconditional means model suggests that the unsold unit ratio differs significantly among housing complexes. The variance within an individual housing complex is $0.0097\left(\sigma_{\varepsilon}^{2}\right.$, level-1 variance), while that among the individual complexes is $0.0149\left(\sigma_{0}^{2}\right.$, level-2 variance). The intraclass correlation coefficient (ICC) is 0.605 , which indicates that $60.5 \%$ of the total variance in the unsold units was due to different characteristics of each housing complex, justifying the use of multilevel growth models.

$$
\mathrm{ICC}=\frac{\sigma_{0}^{2}}{\sigma_{0}^{2}+\sigma_{\varepsilon}^{2}}
$$

\subsection{Unconditional Growth Model}

The result of the unconditional growth model suggests that the addition of the time variable (Time ${ }_{i t}$ ) made a significant fit improvement, producing an increased log likelihood and reduced AIC and BIC compared with the null model (Table 2). The coefficient of the time variable is $-0.026(p<0.01)$, indicating that the unsold unit ratio declined over time in general. With the addition of the fixed and random effects for time, the intraclass correlation increased to $80.2 \%$.

\subsection{Final Model}

The result of the multilevel growth model shows that the communal open spaces inside the housing complexes generate significant effects on the reduction of the unsold housing units. Table 2, Final Model column, presents the fixed effect of the three main question variables: distance to the nearest urban park, distance to the nearest mountain trail, and a dummy variable indicating whether the communal open spaces exceeded $80 \%$ or not. The random effect level-2 variances $\left(\sigma_{0}^{2}=0.4213, \sigma_{1}^{2}=0.0014\right)$ indicate the variance of the mean initial status and the variance of the rate of change, respectively. The estimated covariance between initial status and rates was negative $\left(\sigma_{01}=-0.91\right)$, implying that housing complexes with high initial unsold unit ratio tend to have faster rates of reduction or vice versa.

The fixed effects suggested that the sales of those surplus housing units depend on the communal open space of the housing complex. The coefficients of the dummy and its interaction with time were $0.094(p<0.01)$ and $-0.009(p<0.01)$, respectively, meaning that the ratio of unsold housing units is 0.094 higher in housing complexes with higher coverage of communal open spaces than in the ones of a different condition. The speed of sales of those units, however, is comparatively greater. The surplus units of housing complexes with more communal open space have been sold rapidly: and the ratio of unsold units is reduced by 0.028 per time unit. On the other hand, surplus units of the housing complexes with less communal open spaces are sold at a relatively slower speed: the equivalent coefficient is 0.009 . The distance to the nearest urban park and the distance to the nearest mountain trail entrance had no statistically significant relationship with the dependent variable.

This result means that potential home-buyers are interested in green space inside rather than outside a housing complex in a suburban setting. When assessing the quality of the local living environment, suburban residents valued public green space less than their urban counterparts [70-72]. Urban areas are densely developed, thus the natural or man-made park area per capita is low due to land scarcity [73]. The suburbs, however, are replete with natural environments such as fields, paddies, and mountains. Residents living in the suburbs frequently visit such natural environments [74]. On the other hand, according to a survey on the perceptions of park services in Gyeonggi Province, $42.1 \%$ of the respondents reported that the accessibility of public parks was inconvenient [75]. For that reason, people might choose to use green spaces within the housing complex, and the presence of such spaces of higher quality has become an attraction for home-buyers. 
Table 2 also suggests that other characteristics significantly influence the reduction of unsold units. By controlling other variables, size of housing units were the most influenced

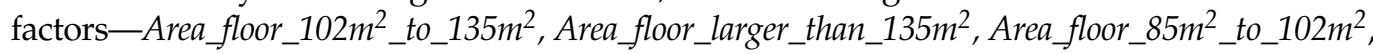
followed by location of amenities_-ln (Dist_Seoul), ln (Dist_Industrial_complex), number of households_-ln (Number_Households), and housing-related policies_Financial_Policy_02/08/ 2017. This result reinforces the idea that the larger units are sold more rapidly than the smaller units. Also, the proximity to the city, industrial complexes, and shopping malls, in order of impact, were positively associated with the reduction of unsold units. This demonstrates that the distance to the jobs and major amenities is important in housing choice [39,40]. A higher number of households in the housing complex positively affects the reduction of unsold units. The total number of households represents the size of the housing complexes, implying that there is a tendency for potential home-buyers to prefer large housing complexes. Large-scale housing complexes are likely to have various facilities and amenities within them for the convenience of the residents, thus they are more popular than smaller-scale ones [32]. Real estate-related regulatory policies and economic factors such as economic growth rate and mortgage rate had significant but uneven effects.

\section{Conclusions and Discussion}

In this study, we investigated the effect of green factors on the reduction of unsold housing stock in the case of housing development projects in Gyeonggi Province, South Korea. Unlike other studies that focus on green characteristics affecting real estate values $[22,25,76-78]$, we assessed the impact of green factors on the purchase of housing units that had not been presold before the completion of construction, using a multilevel growth model. In general, this study demonstrated that the green factors inside the housing complex exerted positive effects on the sales of the surplus housing units. On the other hand, accessibility to the green amenities surrounding the housing complex, such as urban parks and mountain trails, did not do so.

This result accords with previous studies, showing that housing prices rise due to a great view or landscape elements in the complex $[25,76]$. In South Korea, the predominant housing type is a high-rise, high-density complex [32,79], and the contractors of such complexes strive to provide various facilities, such as thematic gardens, plazas, water features, trails, and semi-public recreational facilities. The same trend is also observed in Asian countries, such as China and Malaysia, which have similar residential development patterns [3,51]. The larger the complex, the more communal facilities can be installed within the complex, leading larger complexes to be preferred by home-buyers [80]. The results of our analysis also support this finding. The greater the number of households in a housing complex, the faster the resolution of unsold housing problems.

Urban parks and green spaces in the vicinities of housing complexes are generally favored by home-buyers [22,23], however, some analytical results of our study depart from this observation. The discrepancy might be due to the difference in the environmental setting of our study site. Public urban parks in a densely developed urban area would be a rare amenity that a relatively large amount of financial resources should be paid to procure [73]. Such parks are highly valued by nearby residents [25,81,82]. In suburban development, public urban parks might not be an attraction to residents, because the area is already more natural and forests and/or agricultural fields exist in close proximity to the housing $[74,83]$. Suburban residents, consequently, use public parks less intensively than urban ones [84]. 
The practical implications of this study are as follows. Housing development projects are implemented to address housing shortages, but without a proper understanding of the preference of potential home-buyers, demand may fall short of the supply. This study suggests that high-quality communal open spaces would raise the demand for adjacent housing units even after the initial pre-sale stage. Open spaces within the complex are well managed and well programmed, and - unlike national parks or urban parks-they are exclusive and semi-private green spaces [85].

Other than green amenities, according to our study and as seen in other literature Ref. $[18,19,41,86]$, the closeness of workplaces and hospitals and the larger size of big complexes acted as a significant attraction, helping to resolve the problem of unsold housing units. When building new towns around a fully developed city, a comprehensive planning process might be necessary. Infrastructure, public services, and private destinations should be provided in coordination with existing ones in the cities.

In the case of Korea's third new town development, the central and local governments made a comprehensive plan to proactively procure the necessary infrastructure in line with the residential development [12]. Within the project boundary, land was allocated for major infrastructure; 20 to $40 \%$ was allocated for commercial land, and 30\% was allocated for green spaces [87]. In addition, requirements for amenities inside the residential complex have been increasing; $30 \%$ of space must be green spaces within housing complexes $[30,48,88]$. Similarly, in the city of Shenzhen, China, the National Construction Department has issued a standard for new housing projects that required a green area ratio of at least $30 \%$ when developing high-rise buildings complexes [51].

This study should encourage further research. For more accurate tracking of unsold units, a non-linear multilevel growth model could be used for further study [68,89]. A multilevel linear growth model worked well, with a high model explanation value, but it might not be sufficiently flexible to follow the fluctuation of the ratio of unsold units over time. Also, more detailed data about highly communal open spaces within housing complexes might have improved the accuracy of the analysis. In the current study, the communal open space was represented as a non-coverage area, which includes roads and surface parking lots inside the housing complex. If the data were more detailed, so as to include the number of neighborhood facilities and the exact size of the private garden, it would generate more direct and more accurate guidelines for the construction companies and governments.

The findings of this research will provide hints for solving the problem of unsold housing for construction companies or governments that are conducting housing development projects. It will also be a helpful reference for potential customers deciding whether to purchase unsold housing. This can be generalized for other Asian regions showing a similar housing development pattern.

Author Contributions: Conceptualization, H.Y. (Hayoung Yoo) and H.Y. (Heeyeun Yoon); methodology, H.Y. (Hayoung Yoo) and H.Y. (Heeyeun Yoon); formal analysis, H.Y. (Hayoung Yoo); investigation, H.Y. (Hayoung Yoo); writing—original draft preparation, H.Y. (Hayoung Yoo); writing-review and editing, H.Y. (Heeyeun Yoon); supervision, H.Y. (Heeyeun Yoon); funding acquisition, H.Y. (Heeyeun Yoon). All authors have read and agreed to the published version of the manuscript.

Funding: This work was conducted with the support of the Korea Environment Industry \& Technology Institute (KEITI) through its Urban Ecological Health Promotion Technology Development Project, and funded by the Korea Ministry of Environment (MOE) (2020002770003), the Ministry of Education of the Republic of Korea and the National Research Foundation of Korea (NRF-2017S1A5A8020226), and the Creative-Pioneering Researchers Program through Seoul National University.

Conflicts of Interest: The authors certify that we have no affiliations with or involvement in any organization or entity with any financial interest, or non-financial in the subject matter or materials discussed in this manuscript. 


\section{Appendix A}

Table A1. A detailed explanation, with descriptive statistics, of variables included in the analytical model.

\begin{tabular}{|c|c|c|c|c|c|}
\hline Variables & Description & Mean & St. Dev. & Min & Max \\
\hline Unsold_Unit_Ratio & $\begin{array}{c}\text { Unsold housing ratio } \\
\text { in Gyeonggi Province. } \\
\text { Unsold unit ratio }=(\text { Unsold housing units } / \text { Total housing } \\
\text { units for sale })\end{array}$ & 0.089 & 0.155 & 0.000 & 0.625 \\
\hline Time & $\begin{array}{l}\text { The quarter time of the study period } \\
\text { Distance to the nearest urban park }(\mathrm{km}) \text {, }\end{array}$ & 12.343 & 7.239 & 1 & 25 \\
\hline Dist_Urban_park & $\begin{array}{c}\text { Neighborhood park, Urban agriculture park, Cemetery park, } \\
\text { Culture park, Mini park, Waterside park, Children's park, } \\
\text { Historic park, Sports park, etc. }\end{array}$ & 2.801 & 5.578 & 0.045 & 161.941 \\
\hline $\begin{array}{l}\ln (\text { Dist_ } \\
\text { Mountain_trail) }\end{array}$ & Log of distance to the nearest entrance of mountain trail $(\mathrm{km})$ & 0.250 & 1.239 & -3.219 & 5.038 \\
\hline $\begin{array}{l}\text { Communal_ } \\
\text { OpenSpace }\end{array}$ & \multicolumn{5}{|c|}{$\begin{array}{c}\text { Dummy variable of whether the communal open spaces in unsold housing complex i exceeds } 80 \% \\
\text { or not. }\end{array}$} \\
\hline \multicolumn{6}{|c|}{ Location variables } \\
\hline $\begin{array}{l}\ln (\text { Dist__ } \\
\text { Arterial_road })\end{array}$ & $\begin{array}{l}\text { Log of distance to the nearest thoroughfare }(\mathrm{km}) \text {, } \\
\text { Expressway, General nation road etc. }\end{array}$ & -0.242 & 1.234 & -4.522 & 5.026 \\
\hline $\begin{array}{c}\ln (\text { Dist_- } \\
\text { Subway_station })\end{array}$ & Log of distance to the nearest subway station $(\mathrm{km})$ & 0.681 & 1.06 & -3.602 & 5.171 \\
\hline $\begin{array}{c}\ln \\
\text { (Dist_Industrial_complex) }\end{array}$ & Log of distance to the nearest industrial complex $(\mathrm{km})$ & 1.29 & 0.749 & -2.903 & 3.194 \\
\hline $\begin{array}{l}\ln (\text { Dist_ } \\
\text { Hospital })\end{array}$ & Log of distance to the nearest hospital (km) & 2.184 & 0.909 & -1.995 & 5.117 \\
\hline $\ln$ (Dist_Government_office) & Log of distance to the nearest government office $(\mathrm{km})$ & 2.239 & 0.786 & -1.711 & 5.106 \\
\hline $\begin{array}{c}\ln (\text { Dist_- } \\
\text { Shopping_mall })\end{array}$ & Log of distance to the nearest shopping mall $(\mathrm{km})$ & 1.054 & 0.882 & -4.027 & 5.125 \\
\hline $\begin{array}{l}\ln (\text { Dist_ } \\
\text { CBD_Seoul })\end{array}$ & $\begin{array}{l}\text { Log of distance to the nearest central business districts of } \\
\text { Seoul }(\mathrm{km})\end{array}$ & 3.454 & 0.431 & 2.029 & 5.445 \\
\hline $\ln ($ Dist_Seoul $)$ & Log of distance to Seoul, the capital city of Korea $(\mathrm{km})$ & 2.603 & 0.861 & -1.781 & 5.357 \\
\hline $\ln$ (Dist_River) & Log of distance to the nearest river $(\mathrm{km})$ & -0.735 & 1.033 & -4.515 & 5.025 \\
\hline \multicolumn{6}{|c|}{ Structural characteristics variables of housing complex } \\
\hline Area_floor & $\begin{array}{l}\text { Dummy variable of the floor area of housing unit (area betwe } \\
\text { and } 102 \mathrm{~m}^{2} \text {, between } 102 \mathrm{~m}^{2} \text { and } 135 \mathrm{~m}^{2} \text {, larger than } 135 \mathrm{~m}^{2}\end{array}$ & en $60 \mathrm{~m}^{2}$ & and $85 \mathrm{~m}^{2}$ & etwee & $85 \mathrm{~m}^{2}$ \\
\hline Brand & $\begin{array}{r}\text { Dummy variable of top } 10 \text { brands (apartment constructed by a } \\
\text { top ten in the evaluation each }\end{array}$ & $\begin{array}{l}\text { major co } \\
\text { year) }\end{array}$ & nstruction & company & ranked \\
\hline $\begin{array}{l}\ln (\text { Number_- } \\
\text { Household })\end{array}$ & $\begin{array}{l}\text { Log of number of households in each housing } \\
\text { complex (person) }\end{array}$ & 6.235 & 1.149 & 1.792 & 8.16 \\
\hline \multicolumn{6}{|c|}{ Economic variables } \\
\hline Financial_Policy & \multicolumn{5}{|c|}{$\begin{array}{l}\text { Dummy variable of financial policy-affected time period (enforced at } 1 \text { April 2013; at } 1 \text { September } \\
\text { 2014, at } 28 \text { April 2016, at } 2 \text { August 2017) }\end{array}$} \\
\hline $\begin{array}{l}\text { Economy_- } \\
\text { growth_rate }\end{array}$ & $\begin{array}{l}\text { A measure of economic growth rate from one period to } \\
\text { another using percentage terms (Korea) }\end{array}$ & 4.938 & 0.881 & 2.9 & 5.9 \\
\hline Mortgage_rate & $\begin{array}{c}\text { The rate of interest charged on a mortgage, determined by the } \\
\text { lender and can be either fixed or fluctuating with a } \\
\text { benchmark interest rate (Korea) }\end{array}$ & 3.379 & 0.361 & 2.91 & 4.18 \\
\hline
\end{tabular}

\section{References}

1. Wu, F. China's recent urban development in the process of land and housing marketisation and economic globalisation. Habitat Int. 2001, 25, 273-289. [CrossRef]

2. Ibrahim, M.F.; Ying, W. Public housing choices in Singapore: Planning implications. In Proceedings of the 39th International Planning Congress, International Society of City and Regional Planners, Cairo, Egypt, 17-22 October 2003.

3. Tan, T.-H. Sustainability and Housing Provision in Malaysia. J. Strateg. Innov. Sustain. 2011, 7, 62-71.

4. Groves, R. Housing and the New Welfare State: Perspectives from East Asia and Europe; Routledge: Oxfordshire, UK, 2016. 
5. Tobi, S.U.M.; Jasimin, T.H.; Rani, W.N.M.W.M. Overview of Affordable Housing from Supply and Demand Context in Malaysia. In Proceedings of the IOP Conference Series: Earth and Environmental Science, Ivano-Frankivsk, Ukraine, 21-22 October 2020; IOP Publishing: Bristol, UK, 2020; Volume 409, p. 012010.

6. Kim, H.A. Recent Causes of the Increased Unsold Housings and the Solution. Constr. Econ. Res. Inst. Korea 2007, 21, 1-34.

7. Ling, C.S.; Almeida, S.; Shukri, M.; Sze, L. Imbalances in the property market. BNM Q. Bull. Q. 2017, 3, $26-32$.

8. Zhu, Y.-R.; Ahn, K.-H. A Study on the Development Effects of the New Towns in Beijing Metropolitan Area-Focused on Population and Industry Distribution. J. Urban Des. Inst. Korea Urban Des. 2007, 8, 89-104.

9. Ju, S.R.; Jeon, S.Y. A Study on the Planning and its Periodic Changes of Public Housing in Malaysia. Southeast Asian Rev. 2012, 22, 207-245.

10. Ha, S.K. Metropolitan New Town and Housing Problem. Archit. Inst. Korea 1995, 39, 44-47.

11. Park, I.K. The Current Status and Prospect of New Town Housing, Korean Social Trends 2019 Statistics Research Institute 2019; SRI: Daejeon-si, Korea, 2019; pp. 250-260.

12. Land and Housing Institute. Research on the establishment of the 3rd new town development strategy and planning standards. Land Hous. Insttitute J. 2020, 2020, 2016.

13. Jang, S.; Lee, S.; Kim, J.; Kim, J. Relationship between demand-supply in the housing market and unsold new housing stocks. J. Asian Archit. Build. Eng. 2010, 9, 387-394. [CrossRef]

14. Jo, Y.S.; Kim, J.J. A Study on the Decision Making Model of Unsold Houses (Apartment). Resid. Environ. Inst. Korea 2010, 8, 241-251.

15. Molloy, R. Long-term vacant housing in the United States. Reg. Sci. Urban. Econ. 2016, 59, 118-129. [CrossRef]

16. Loibl, W.; Toetzer, T. Modeling growth and densification processes in suburban regions-simulation of landscape transition with spatial agents. Environ. Model. Softw. 2003, 18, 553-563. [CrossRef]

17. Nelson, A.C.; Pendall, R.; Dawkins, C.J.; Knaap, G.J. The link between growth management and housing affordability: The academic evidence. Growth Manag. Afford. Hous. Confl. 2002, 117, 158.

18. Munroe, D.K. Exploring the Determinants of Spatial Pattern in Residential Land Markets: Amenities and Disamenities in Charlotte, NC, USA. Environ. Plan. B Plan. Des. 2007, 34, 336-354. [CrossRef]

19. Cervero, R.; Day, J. Residential Relocation and Commuting Behavior in Shanghai, China: The Case for Transit Oriented Development; UC Berkeley Center for Future Urban Transport: Berkeley, CA, USA, 2008.

20. Kang, K.A.; Kim, J.J. A Study on the Factors Affecting Unsold house in the Changes of Macro-economic Variables. Resid. Environ. Inst. Korea 2017, 15, 193-207. [CrossRef]

21. Jim, C.; Chen, W.Y. Impacts of urban environmental elements on residential housing prices in Guangzhou (China). Landsc. Urban. Plan. 2006, 78, 422-434. [CrossRef]

22. Kolbe, J.; Wüstemann, H. Estimating the value of urban green space: A hedonic pricing analysis of the housing market in Cologne, SFB 649 Discussion Paper, Germany. Acta Univ. Lodz. Folia Oeconomica 2014, 5, 307.

23. Yuen, B.; Hien, W.N. Resident perceptions and expectations of rooftop gardens in Singapore. Landsc. Urban. Plan. 2005, 73, 263-276. [CrossRef]

24. Hu, S.; Yang, S.; Li, W.; Zhang, C.; Xu, F. Spatially non-stationary relationships between urban residential land price and impact factors in Wuhan city, China. Appl. Geogr. 2016, 68, 48-56. [CrossRef]

25. Lee, J.S.; Kim, J.; Son, Y.H. A Study on the Influences of Environmental Factors on the Apartment Price: Focused on View Quality and Park Accessibility in Songdo Newtown. Korea Real Estate Rev. 2013, 23, 99-121.

26. Zhang, L.; Sun, C.; Liu, H.; Zheng, S. The role of public information in increasing homebuyers' willingness-to-pay for green housing: Evidence from Beijing. Ecol. Econ. 2016, 129, 40-49. [CrossRef]

27. Haaland, C.; van Den-Bosch, C.K. Challenges and strategies for urban green-space planning in cities undergoing densifi-cation: A review. Urban For. Urban Green. 2015, 14, 760-771. [CrossRef]

28. Zalejska-Jonsson, A.; Wilkinson, S.J.; Wahlund, R. Willingness to Pay for Green Infrastructure in Residential Develop-ment-A Consumer Perspective. Atmosphere 2020, 11, 152. [CrossRef]

29. Hong, K.-G. The Influences of Apartment Complex Characteristics on Housing Price by Hierarchical Linear Model. J. Korean Hous. Assoc. 2014, 25, 39-47. [CrossRef]

30. Park, I.S.; Eom, Y.S.; Eom, S.W. Apartment in green area index calculation and analysis of the impact of housing prices: The case of the Jeonju. J. Korean Reg. Econ. 2016, 34, 113-129.

31. Xiao, Y.; Li, Z.; Webster, C. Estimating the mediating effect of privately-supplied green space on the relationship between urban public green space and property value: Evidence from Shanghai, China. Land Use Policy 2016, 54, 439-447. [CrossRef]

32. Ko, H.R.; Song, S.J.; Shin, J.C. An Analysis on the Influencing Factors on the Sales Rates of Apartment Complexes-Focused on the Housing Characteristics of Apartment Unit Types. Resid. Environ. Inst. Korea 2018, 16, 159-177. [CrossRef]

33. Tak, J.-H.; Rho, J.-H. Decision-making Factors and Characteristics for Buying an Unsold Apartment: Focused on Unsold Apartment Residents. J. Korea Acad. Ind. Coop. Soc. 2017, 18, 229-238.

34. Kang, M.S. Unsold Apartments Status and Possible Growth; KB Financial Group: Seoul, Korea, 2018.

35. Shin, K.J. New Apartment Burned out Unsettled Residents. Available online: http://www.jbnews.com/news/articleView.html? idxno=419781 (accessed on 12 February 2012). 
36. Poovenraj. Vacancy Tax-Timely Solution to Problem of Property Overhang. Available online: https:/ /www.businesstoday.com. my/2020/09/11/vacancy-tax-timely-solution-to-problem-of-property-overhang/ (accessed on 11 September 2020).

37. Choi, J.-K.; Yoo, S.-K.; Kim, J.-J. Relationship Between the Default Risk of a Construction Company and Unsold Housing Stock. J. Archit. Inst. Korea Struct. Constr. 2013, 29, 89-96.

38. Song, I.H. "After Building the Apartment, Select the Desired Unit" ... Attention to the After-Sale System. Available online: https:/ /biz.chosun.com/site/data/html_dir/2017/11/19/2017111901935.html (accessed on 20 November 2017).

39. Liu, Y.; Yue, W.; Fan, P.; Song, Y. Suburban residential development in the era of market-oriented land reform: The case of Hangzhou, China. Land Use Policy 2015, 42, 233-243. [CrossRef]

40. Shen, J.; Wu, F. Moving to the Suburbs: Demand-Side Driving Forces of Suburban Growth in China. Environ. Plan. A Econ. Space 2013, 45, 1823-1844. [CrossRef]

41. Kim, D.; Lee, S. The Effect of Characteristics of Apartment Complex on the Count Rate of House Transaction. J. Korea Real Estate Anal. Assoc. 2018, 24, 53-68. [CrossRef]

42. Hur, J.W.; Son, S.M. An Empirical Analysis on Regional Effect of the Unsold Housing Policy. J. Korea Plan. Assoc. 2013, 48, 131-147.

43. Kwon, H.S.; Bang, D.W. Effects of Demand-Side Housing Policies on New Apartment Unsold Rates. J. Korea Real Estate Anal. Assoc. 2016, 22, 5-16.

44. Kim, Y.H. Factors of Relocation of the Residents to the Second New-Town-Focusing on the residents who relocated from the "first" new-towns and those who relocated from outside the new-towns. J. Geogr. 2014, 60, 83-112.

45. Lee, G.-K.; Lee, J.-H. A Study on the Solution of Unsold Houses through User Centered Marketing Strategies. J. Korea Acad. Coop. Soc. 2014, 15, 1318-1326. [CrossRef]

46. Tak, J.H.; Rho, J.H. A Study on the Decision-making Factors of Living-in Idea into Unsold Apartment of Metropolitan Area. J. Korea Contents Assoc. 2017, 17, 247-255.

47. Czembrowski, P.; Kronenberg, J. Hedonic pricing and different urban green space types and sizes: Insights into the discussion on valuing ecosystem services. Landsc. Urban Plan. 2016, 146, 11-19. [CrossRef]

48. Eom, Y.S.; Choi, A.S.; Kim, S.G.; Kim, J.O. A hedonic valuation of urban green space in Seoul, Korea. Environ. Resour. Econ. Rev. 2019, 28, 61-93.

49. Trojanek, R.; Gluszak, M.; Tanas, J. The effect of urban green spaces on house prices in Warsaw. Int. J. Strat. Prop. Manag. 2018, 22, 358-371. [CrossRef]

50. Choi, S.R.; Eom, Y.S. The amenity value of urban green spaces in Seoul: A choice experiment approach. Korea Environ. Econ. Assoc. 2017, 2017, 53-76.

51. Chen, W.Y.; Jim, C. Amenities and disamenities: A hedonic analysis of the heterogeneous urban landscape in Shenzhen (China). Geogr. J. 2010, 176, 227-240. [CrossRef]

52. Choi, E.Y.; Koh, S.S.; Kim, M.S. A Study on the Determinants of Apartment Premiums in Korea. Korea Real Estate Rev. 2011, 21, 235-254.

53. Lee, D. Statellite View of Housing Complex in Wirye New Town. Available online: https:// file.mk.co.kr/meet/neds/2018/03/ image_readtop_2018_187721_15217812583249013.jpg (accessed on 24 August 2020).

54. Lee, H.; Kim, K.; Moon, J.; Kim, T.; Lim, Y.; Shin, S.; Kim, I.; Lee, Y. Eye Level View of the Communal Open Space in Housing Complex in Wirye New Town. Available online: https:/ / file.mk.co.kr/meet/neds/2016/07/image_readtop_2016_521485_1469 5939602553117.jpg (accessed on 24 August 2020).

55. Yoo, G.S. Ui Uijeongbu City, The G\&B Project Urban Park Project. Available online: http://www.kgmaeil.net/news/photo/2020 02/232844_41623_490.jpg (accessed on 6 February 2020).

56. Forest Social Press Corp. Wonsusan Mountain, a Forest Overlooking the City at a Glance. Available online: https: / / img1.daumcdn.net/thumb / R1280x0/?scode=mtistory2\&fname=https $\% 3 \mathrm{~A} \% 2 \mathrm{~F} \% 2 \mathrm{Fblog}$. kakaocdn.net $\% 2 \mathrm{Fdn} \% 2 \mathrm{FbhCxif} \%$ 2FbtqHEepNlq9\%2Fkb6TQy4vMFOncw4Mh48Yx0\%2Fimg.jpg (accessed on 1 September 2020).

57. The Enforcement Decree of the National Land Planning and Utilization Act, Presidential Decree No.27052; Korea Law Information Center: Sejong-si, Korea, 2016; Volume 86.

58. Jung, S.H. Why 35th floor-Background and meaning of Seoul's height management standards. Seoul Solut. World Cities 2018, 21, 16-23.

59. Yoon, A.Y. “The Lower the Better" ... Considering the Coverage Ratio, You Can See a Pleasant Apartment. Available online: https:/ / www.hankyung.com/realestate/article/2015082813291 (accessed on 28 August 2015).

60. Ministry of Land Infrastructure and Transport. 2018 Korea Housing Survey; Ministry of Land Infrastructure and Transport: Sejong-si, Korea, 2019.

61. Tasca, G.A.; Illing, V.; Ogrodniczuk, J.S.; Joyce, A.S. Assessing and adjusting for dependent observations in group treatment research using multilevel models. Group Dyn. Theory, Res. Pract. 2009, 13, 151-162. [CrossRef]

62. Rabe-Hesketh, S.; Skrondal, A. Multilevel and Longitudinal Modeling Using Stata; STATA Press: College Station, TX, USA, 2012.

63. McCoach, D.B.; Kaniskan, B. Using time-varying covariates in multilevel growth models. Front. Psychol. 2010, 1, 17. [CrossRef]

64. Qiu, J.; Li, R.; Xiao, Y.; Xia, J.; Zhu, H.; Niu, Y.; Huang, D.; Shao, Q.; Cui, Y.; Wang, Y. Spatiotemporal Heterogeneity in Human Schistosoma japonicum Infection at Village Level in Hubei Province, China. Int. J. Environ. Res. Public Health 2019, 16, 2198. [CrossRef] 
65. Fazio, G.; Piacentino, D. Convergence analysis for hierarchical longitudinal data. Econ. Model. 2018, 73, 89-99. [CrossRef]

66. Singer, J.D.; Willett, J.B. Applied Longitudinal Data Analysis: Modeling Change and Event Occurrence; Oxford University Press: Oxford, UK, 2003.

67. Steele, F. Multilevel models for longitudinal data. J. R. Stat. Soc. Ser. A Stat. Soc. 2007, 171, 5-19. [CrossRef]

68. Tu, Y.-K.; Chiu, Y.-W.; Pandis, N. Analyzing longitudinal orthodontic data. Part 1: Multilevel linear and curvilinear models. Am. J. Orthod. Dentofac. Orthop. 2013, 144, 481-486. [CrossRef] [PubMed]

69. Khatiwada, A. Multilevel Models for Longitudinal Data. Electronic Theses and Dissertations; East Tennessee State University: Johnson City, TN, USA, 2016.

70. Arnberger, A.; Eder, R. The influence of green space on community attachment of urban and suburban residents. Urban. For. Urban. Green. 2012, 11, 41-49. [CrossRef]

71. Özgüner, H.; Kendle, A. Public attitudes towards naturalistic versus designed landscapes in the city of Sheffield (UK). Landsc. Urban. Plan. 2006, 74, 139-157. [CrossRef]

72. Pisman, A.; Allaert, G.; Lombaerde, P. Urban and suburban lifestyles and residential preferences in a highly urbanized society. Belgeo 2011, 1-2, 89-104. [CrossRef]

73. Sung, J.S. A study on the integrated creation and management of parks, green areas and urban forests in cities. Korea For. Serv. 2007, 1-189.

74. Zawilińska, B. Residents' attitudes towards a national park under conditions of suburbanization and tourism pressure: A case study of Ojcow National Park (Poland). Eur. Countrys. 2020, 12, 119-137. [CrossRef]

75. Kim, H.S. Environmental issue: Controversy over imbalances in park services. (Gyeonggi Research Institute pending issue pol-icy analysis data). 2015.

76. Aridou, I.O.; Alescio, N.R.; Mair, R.E. An Assesment of the Preferences of Urban Residents for Green Space; Worcester Polytechnic Institute: Worcester, MA, USA, 2019.

77. Łaszkiewicz, E.; Czembrowski, P.; Kronenberg, J. Can proximity to urban green spaces be considered a luxury? Classifying a non-tradable good with the use of hedonic pricing method. Ecol. Econ. 2019, 161, 237-247. [CrossRef]

78. Xiao, Y.; Lu, Y.; Guo, Y.; Yuan, Y. Estimating the willingness to pay for green space services in Shanghai: Implications for social equity in urban China. Urban. For. Urban. Green. 2017, 26, 95-103. [CrossRef]

79. Choi, C.G.; Lee, S. Suburbanization in Asia: A Focus on Seoul; Routledge: Oxfordshire, UK, 2018; pp. 121-132.

80. Yang, H.J. Agglomeration Economies in Multi-Family Housing Estate Developments in Korea: Internalization and Enlargement of Public and Commercial Facilities. Ph.D. Thesis, Graduate School of Environmental Studies, Seoul National University, Seoul, Korea, 2017.

81. Jim, C.; Shan, X. Socioeconomic effect on perception of urban green spaces in Guangzhou, China. Cities 2013, 31, 123-131. [CrossRef]

82. McConnell, V.; Walls, M.A. The Value of Open Space: Evidence from Studies of Nonmarket Benefits; Resources for the Future Washington: Washington, DC, USA, 2005.

83. Nicholls, S.; Crompton, J.L. Impacts of Regional Parks on Property Values in Texas. J. Park Recreat. Adm. 2005, $23,87-108$.

84. Loukaitou-Sideris, A.; Sideris, A. What brings children to the park? Analysis and measurement of the variables affecting children's use of parks. J. Am. Plan. Assoc. 2009, 76, 89-107. [CrossRef]

85. Sarkissian, W.; Bateman, R.; Hurley, B. Open space in medium-density housing guidelines for planning and design. Nimbin NSW 2013, 2480.

86. Rachmawati, D.; Shukri, S.; Azam, S.M.F.; Khatibi, A. Factors influencing customers' purchase decision of residential property in Selangor, Malaysia. Manag. Sci. Lett. 2019, 9, 1341-1348. [CrossRef]

87. Kim, Y.S.; Jang, K.S. Characteristics of the 3rd New City Policy and The Future Tasks (NARS Report-1713); National Assembly Research Service. NARS: New York, NY, USA, 2020.

88. The Enforcement Decree of the National Land Planning and Utilization Act, Presidential Decree No.21443; Korea Law Information Center: Sejong-si, Korea, 2009; Volume 27.

89. Strathe, A.B.; Danfær, A.; Sørensen, H.; Kebreab, E. A multilevel nonlinear mixed-effects approach to model growth in pigs. J. Anim. Sci. 2010, 88, 638-649. [CrossRef] [PubMed] 